\title{
Educational Connotations Derived from the Rulings of the Disputes and the Judiciary in the Holy Quran and the Prophet's Sunnah
}

\section{Marwa Salem Nouri}

Iraq - Ministry of Higher Education and Scientific Research - DiyalaUniversity - Faculty of Education for Pure Sciences

\footnotetext{
Abstract

Research Extract

The problem of research: The problem of research lies in answering the following question: What are the educational connotations derived from the rulings of the litigants and the judiciary in the Holy Quran and the Prophet's Sunnah?

The importance of research: The importance of study ing is shown by the following:

- To reveal the extent to which Islam is concerned with the provisions of the disputes for the spread of peace, justice and equality at the individual and societal levels.

- Disclosure of jurisprudence and its educational implications relating to the provisions of the disputes for their practice in the public and private life of the individual.

- $\quad$ The study gives a new addition to the Iraqi Library in the field of education philosophy.

The objective of the research: The current research aims to reveal the educational connotations derived from the provisions of the disputes and the judiciary in the Holy Quran and the Prophet's Sunnah.

Search limits:
}

Article Received: 16th October, 2020; Article Revised: 30th December, 2020; Article Accepted: 08th January, 2021

in order to prevent injustice and injustice.

2. Islam emphasized the upbringing of individuals and training them in justice and fairness before judging others.

3. Islam emphasized the upbringing of individuals on tolerance and reform among adversaries, to eliminate discord and to spread love and affection among people.

4. Islam emphasized the upbringing and education of individuals that it has the right to defend itself, say what it has the right to, and to hear the point of view of its adversary, so that it can be judged by justice and truth.

5. Islam emphasized the upbringing and upbringing of individuals to respect their rights and the rights of others, and not to be unjust in all its forms and colours.
1. The current research is determined by the educational implications of the provisions of the disputes and thejudiciary.

2. Relying on the 23 verses of the Qur'anicverses.

3. Relying on the 12 structural conversations recently.

4. Relying on the mothers of books that have been discussed in detail in the topics of the provisions of the disputes.

Research methodology: The descriptive and inference method was used to achieve the research objective:

Presentation and interpretation of the results: The study reached the following results:

1. Islam emphasized the upbringing of individualson dream, wisdom, and good behavior, especially when ruling between adversaries, 
matter of virtue, injustices and injustices are answered, and reform among the people (Ibn Qadama, 1997: 89, 153).

The Sunnah also sought to resolve the rivalry between the members of the community, to repair the same differences, and to mediate between the adversaries, in order to raise the antagonism by consent, side by side with sedition, and thereforethe Prophet Peace be upon him wasreforming himself among the adversaries amongthe members of the society; TheProphet said:"May God allow him to sell, allow if he buys, if he buys, If necessary," (Bukhari, 1987: 2076), (Al-Termi, DT: 1320), (Ibn Maja, D.T., 2003).

The Prophet called for the reform of€ hearts and deeds, as he said:€ "God does not look at your pictures and your money, but he looks at your hearts and deeds." (Muslim, D.T.: 6708).

The Prophet also affirmed the Peace be upon him liberation of the soul from hatred, hatred, hatred, and envy, as he said: Peace be upon him (Don't be exasperated, don't envy, and be the servantsof God arebrothers) (Bukhari, 1987: 6066), (Abu Dawood, D.T.: 4) They Peace be upon him said: Yes, he said: reform of the same thing, and corruption of the same kind of sabernatic) (Abu Dawood, D.T.: 4919), (Al-Termi, D.T.: 2509).

It is clear from the foregoing that the Holy Qur'an and sunnah called for the abandonment of rivalries, and the Muslim should be polite about the morality of the quarrel if there is any kind of quarrel between the members of the society, and this is the message of Islam in how to preserve the unity of society and keep it from disintegration and rivalry.

So the importance of study is shown by the following:

1. To show the extent to which Islam is concerned with the provisions of the disputes.
6. Islam emphasized the upbringing of individuals on the equality of people, because justice and equality are the basis of the country's stability.

7. Islam emphasized the upbringing of individuals and training them in truth, telling the truth, and warning them against perjury.

8. Islam emphasized educating individuals and guiding them to know the rulings of inheritance.

In the light of the results of the research, the researcher came up with a set of recommendations and proposals.

Search problem:

The problem of research ing lies in the extent to which the phenomenon of conflict among members of Iraqi society is widespread because of the political, economic and social situations. In customs, traditions, tendencies, trends, desires, and needs, all these factors encouraged the emergence of the phenomenon of rivalry, which resulted in hostile behaviors, conflict among some, as well asthe result of family disintegration, social rupture, the emergence of conflict between husbandand wife, between members of the same family, and between the neighbor and his neighbor and in light of the widespread phenomenon of conflict between members of society, was the desire of the researcher to study and seek to answer the following question What are the educational connotations derived from the provisions relating to the hadiths and the judiciary in the Holy Qur'an and the Prophet's Sunnah?

The importance of research:

The Holy Qur'an is the constitution of Muslims; Therefore, the Islamic religion has called on wise and wise people to establish government, mediate disputes and disputes between people, and reform themselves, and called for action to clear hearts from the hatreds resulting from the rivalry, because in the judiciary it is a 
2. Inference: ArFah Ibn Mansoor $(1423$ Ah) as:"extraction, the inference of the jurist, and the extraction of thejurisprudence with its jurisprudence and understanding" (Ibn Masrif, 1423 Ah, c. 8:433).

3. The ruling is a term: Al-Husari (1982) defined it as "proof of an order and denied it" (Al-Husari, 1982: 7).

4. Disputes: Mitchell, 1981 defined it as "any case in which there are two social parties who perceive their objectives incompatible" (Mittchell,1981).

5. The Prophet's Year: Al-Sibai (1982) defined it as: "What influenced thePeace be upon himProphet() by saying, doing, deciding, or morally, whether before or after the mission, and for this reason to be synonymous with hadith to some of them" (AlSibai, 1982: 47).

\section{Research methodology:}

According to the nature of the research, the descriptive and inference approach will be used in achieving the current research objective, and the inference method is defined as: "The methodology based on the consideration of texts and sayings, study and analysis, and the attempt to extract the provisions, sermons, and secrets" (Al-Dwehi and Rasheed, 142Ah: 25), the inference approach has been followed as follows:

1. Collecting the Qur'anic verses, dividing them and descending them on the axes of thestudy, the number of verses has reached 23.

2. Collecting prophetic hadiths, graduatingthem, dividing them, and downloading them to the themes of the study, and the number of (13) recently.

3. Collecting the terms of the conditions of the correct disputes from most of the books of
2. Disclosure of jurisprudential provisions and their educational implications relating to the provisions of disputes, for their practice in public and private life.

3. The currentstudy gives a new scientific addition to the Iraqi Library in the field of educationphilosophy.

\section{Search goal:}

The current research aims to reveal the educational connotations derived from the provisions of the disputes and the judiciary in the Holy Quran and the Prophet's Sunnah.

Search limits:

The current research is determined by:

1. Themostheyed of the quarrels and the judiciary in the Qur'an and the Prophet's Sunnah.

2. The reliance on qur'anic verses analyzed from a deliberate sample of Qur'anic verses governing the resolution of disputes, numbering 23.

3. Relying on the prophetic hadiths that were graduated andanalyzed from a deliberate sample of prophetic hadiths that regulate the resolution ofdisputes in the Prophetic biography, the number of (13) recently.

4. Relying on the mothers of the jurisprudential books, which dealt with the topics of the provisions of the disputes and the judiciary in all its aspects.

\section{Select terms:}

1. Educational connotations: A.H.Al-Jarjani $(1413 \quad \mathrm{H})$ : "The fact that the object is in a state of knowledge of something else, and the first thing is the evidence, and the second is the meaning" (AlJarjani, 1413 H: 139). 
judgment, Peace be upon himPeace be upon him such as his saying: (i.e., the two righteous) to God on the platforms of Noor, on the right of rahman Almighty, and both hands areright, who adjust their judgment, their parents, and what they are doing) (Muslim, D.T.: 1827), (women, 1991 AD: 5394), imam Ali said(imam) $\square$ (Muslim, D.T.: 1827), (women, 1991 AD: 5394), Imam Ali said(Imam Ali) (Muslim, D.T.: 1827), (women, 1991 A.d.: 53994)Peace be upon him Hesaid: "God will guide your heart and prove your tongue; if you sit in your hands of the two opponents, do not judge until you hear from the other, as I heard from the first one; 8420), (Ibn Maja, DT: 2310).

3. To raise individuals and train them to tolerate and reform between adversaries, to remove quarrels and disputes, and to spread love and affection and to be known among the people, because he sought something that would have done well,Peace be upon himPeace be upon him and he had a stake in it;(4919),(AlTermi, D.T.: 2509), as well as the saying of the Messenger ofGod((Muslim brother of the Muslim does not oppress him or deliver him, who ever needed his brother, God was in need, and who is the virgin of a Muslim who is a wife of God, who is a woman who is a woman on the Day of Resurrection), and who is a Muslim jacket on the Day Peace be upon him of Resurrection) (Bukhari, 1987 AD: 2442), (Muslim, D.T.: 2580).

4. Raising individuals andteachingthem that he has the right to defend himself, say what thescholars, and deriving some of these conditions from the words of the interpreters in the examples.

4. I will make the application and mention examplesoftheoretical research, in the research without being separated by a separate section, because this includes a greater clarification of theoretical issues, and to avoid repetition.

5. I will document the scientific material in the research as follows:

A- He attributed the verses in the research to her compatriot in the Holy Qur'an, and mentioned the name of the surah and the number of the verse.

B- Graduation of the hadiths contained in the research from the sources of the year approved by mentioning the sources, part, page, and number of hadiths if any.

C- Documenting the words conveyed by scientists by referring to their positions in the research in a brief definition.

View and interpret the results:

The study reached the following conclusions:

Thejudiciary is a great placein Islam;

The most important educational implications in this area are:

1. The prophet also stressedthePeace be upon himgood behavior of the ruling, saying:Peace be upon $\operatorname{him}($ No one rules between two) and he is angry) (Bukhari, 1987) : 7158), (Muslim, D.T.: 1717), (Abu Dawood, D.T.: 589), Termadi, D.T.: 1443), (Feminist, 1991: 5406).

2. The Prophet also affirmed the practice of justice and fairness in 
king of liars, and a arrogant breadwinner). (Muslim, D.T.: 106), (Abu Dawood, D.T.: 4087), (Termadi, D.T.: 1211), (Feminist, 1991: 2564), (Ibn Maja, D.T. 2208).

8. The Prophetof€ God said:"I am the first believer son of the believers than himself, and whoever dies with a religion and does not leave a Peace be upon himreligion, we have to spend it, and who leaves the mala he inherited") (Bukhari, 1987: 6379), (Muslim, D.T.: 1619),(Ibn Hajar, 1379,c12:11).

We conclude from the foregoing that the educational implications are aimed at raising awareness of the direction of peace and rejecting conflict, in order to build a generation that believes in justice, equality and peace at the individual and societal levels.

Recommendations:

In light of the results of the research, the researcher recommends:

1. Educational and social institutions adopt the concept and factors to inform young people about the rules of the disputes, through a correct understanding of the Qur'an, the Prophet's Sunnah and the diligence of Muslim scholars.

2. The researcher recommends that all members of society should apply the educational connotations of the provisions of the disputes derived from the Holy Quran and the Prophet's Sunnah, for the purpose of maintaining justice, equality, and peace at the individual and societal levels.

\section{Proposals:}

To complete the current research, the researcher presents the following proposals:

1. Conducting a study to reveal the educational values derived from the provisions relating to the worship of the individual in the he has the right, and to name the point of view of his opponent, so that he can judge them with justice and truth, and does not swear to falsehood;Peace be upon him (Ibn Maja, Dit: 1721), asthe Prophet of Godsaid: Peace be upon him (From an oath on the right of reparation with which the money of a Muslim woman is cut, God was found to be angry)) (Bukhari, 1987: 6676), (Muslim, D.T.: 138).

5. The Prophet warned Peace be upon him against injustice in all its forms, and he said:"Fear injustice; injustice is the darkness of the Day ofPeace be upon him Resurrection") (Muslim, D.T.: 2578), and his saying When Peace be upon himMuathibnJabal( $\square)$ senthim to Yemen, he said: "I am sending the call of the oppressed, it is not between them and Allah hijab."

6. Raising and training individuals in equality without discrimination or discrimination on the basis of religion, gender, race, colour, face or descent; The Prophet ()Peace be upon himthe administration of justice and equality; Peace be upon him 8: 3331), as well as his saying: Peace be upon him(Muslims are rewarded with their blood and seek sought by their selves below them, and they are answered at their most, and they are the hands of others, and a Muslim is not killed by an infidel or a covenant under his reign)(Abu Dawood, D.T. 4530), (Feminist, 1991: 4734),(Al-Bagui, $1983, \quad$ C5: 3888), (Governor, 1990, C2: 141).

7. He said:Peace be upon him(Three are not spoken by Allah on the Day of Resurrection, and do not recommend them, and they have painful torment, Sheikh Zan, a 
Investigation:

Mohammed

Mohieddin Abdul Hamid Al-Azdi, J1, Dar al-Fikr, Beirut.ehavior, pp.120-142.

- Al-Sibai, Mustafa (1982): Sunnis and their place in Islamic legislation, Islamic Bureau, Beirut.

- Al-Dwehi, Ahmed bin Abdullah, and Al-Rasheed, Ahmed bin Abdulrahman (1432H): Guide to writing scientific letters and complementary research at Imam Mohammed bin Massoud Islamic University, Riyadh.

- Ibn Qadama, Abu Mohammed Muwaffaq al-Din Abdullah bin Ahmed (1997): Singer, C10, Dar AlAlam, Riyadh.

- Ibn Maja, Abu Abdullah Mohammed bin Farid al-Qazwini (D.T.): Sinan Ibn Maja, Al-Resala Foundation, Beirut.

- Muslim, Abu al-Hussein bin al-Hajjaj al-Qashiri al-Nisaburi (D.T.): Sahih Muslim, Investigation: Mohammed Fouad Abdel Baki, Heritage Revival House, Beirut.

- Ibn Mansoor, Muhammad ibn Makram al-Ansari (1423 Ah), Tongue of the Arabs, Cairo.

- Al-Sa'ad, Abu AbdulRahman Ahmed Bin Shabib (1991): Al-Sinan alKabir, Investigation: Abdul Ghaffar Suleiman al-Bandari, T1, Scientific Books House, Beirut.

- Al-Hrawi, Ali ibn Sultan Muhammad Abu al-Hassan Noureddine (1422Ah): The key mark is the explanation of the lamps, Dar al-Fikr, Beirut.

- Mithchell, C. R. 1981, The Structure of International Conflict. Macmillan, Part. 1, The Structure of Conflict, pp.15-46, The Structure
Holy Qur'an and the Prophet's Sunnah.

2. Conducting a study on the educational connotations derived from the provisions relating to financial transactions in the Qur'an and the Prophet's Sunnah.

\section{References :}

The Holy Quran.

- Al-Bukhari, Abdullah Ismail bin Ibrahim (1987): Sahih Al-Bukhari, Investigation: Mustafa Deeb AlBaga, Beirut.

- Al-Bagui, Hussein bin Masood bin Muhammad bin Al-Fur Abu Muhammad (1983): Explanation of the Sunnah, Investigation: Shoaib AlArnaout, Islamic Bureau, Cairo.

- Al-Termadi, Mohammed Bin Isa (D.T.), Sinan Al-Termadi, Investigation: Ahmed Mohammed Shaker, Heritage Revival House, Beirut.

- Al-Jarjani, Ali bin Mohammed alSayyid al-Sharif (1413H): Definitions, Investigation: Mohammed Siddiq Al-Manshawi, Cairo.

- The Ruler, Abu Abdullah Mohammed bin Abdullah al-Nisaburi (1990): The Right One, Investigation: Mustafa Abdelkader Atta, Scientific Book House, Beirut.

- Ibn Hajar, Ahmed Ibn Ali alAshkeloni (1379 Ah): Fath al-Bari explained Sahih Al-Bukhari, investigation: Mohammed Fouad Abdel Baki and Mohibaldin AlKhatib, Dar al-Laqram, Beirut.

- Al-Husari, Ahmed (1982): The Theory of Governance and The Sources of Legislation in Islamic Jurisprudence, Al-Azhar College Library, Cairo.

- Abu Daoud, Suleiman bin Al-Shaath al-Sijistani (D.T.): Sinan Abi Daoud, 